\title{
Field Performance of Rhizobial Inoculants on Lentil
}

\author{
MAsadul Haque Bhuiyan ${ }^{1 *}$, Delowara Khanam², M Eyakub Ali ${ }^{3}$, Fardul Alam³ and M Arifur Rahman ${ }^{4}$ \\ ${ }^{1}$ Senior Scientific Officer, Soil Science Division, Bangladesh Agricultural Research Institute, Gazipur-1701, Bangladesh; ${ }^{2}$ Principal Scientific Officer, \\ Soil Science Division, Bangladesh Agricultural Research Institute, Gazipur-1701, Bangladesh; ${ }^{3}$ Scientific Officer, Soil Science Division, Bangladesh \\ Agricultural Research Institute, Gazipur-1701, Bangladesh; ${ }^{4}$ Scientific Officer, Soil Science Division, Regional Agricultural Research Station, \\ Jamalpur, Bangladesh
}

(Received 10 April 2010; Accepted 21 August 2010)

\begin{abstract}
A field experiment was conducted at Regional Agricultural Research Station (RARS), Jamalpur during rabi season of 2005-2006 and 2006-2007 to find out the effectiveness of Rhizobium strains on lentil. BARI Masur4 and Rhizobium inoculum (strains BARI RLc-104, BARI RLc-105, BARI RLc-106 and BARI RLc-107) were used in this experiment. Unit plot size was $4 \mathrm{~m} \times 3 \mathrm{~m}$. The experiment was designed in randomized complete block having 4 replications for each treatment. There were six treatments, $\mathrm{T}_{1}$ : Rhizobium strain BARI RLc104, $\mathrm{T}_{2}$ : Rhizobium strain BARI RLc-105, $\mathrm{T}_{3}$ : Rhizobium strain BARI RLc-106, $\mathrm{T}_{4}$ : Rhizobium strain BARI RLc107, $T_{5}$ : mixed culture of the above four strains and $T_{6}$ : control. The strains were used to prepare peat based rhizobial inocula which were used @ $1.5 \mathrm{~kg} \mathrm{ha}^{-1}$. A basal dose of $\mathrm{P}, \mathrm{K}, \mathrm{S}, \mathrm{Zn} @ 22,42,20,5 \mathrm{~kg} \mathrm{ha}^{-1}$, respectively for all treatments were used in the experiment. Plant receiving peat based rhizobial inocula (strain BARI RLc-104, BARI RLc-105, BARI RLc-106, BARI RLc-107 and mixed culture) produced significantly higher nodule number, nodule weight, stover yield and seed yield over non-inoculated control. The highest nodule number (12.84 plant $^{-1}$ in 2006 and 12.30 plant $^{-1}$ in 2007) and nodule weight (10.51 mg plant $^{-1}$ in 2006 and 13.53 mg plant $^{-1}$ in 2007) were found with strain BARI RLc-104. This strain also recorded the highest seed yield (1.23 t ha-1 $55.7 \%$ higher over non-inoculated control) in 2006 but BARI RLc-107 produced the highest seed yield (1.20 t ha-1, $50.0 \%$ higher over non-inoculated control) in 2007 though all the strains including mixed culture recorded identical yields.
\end{abstract}

Key words: Rhizobium, lentil, nodulation, yield

\section{Introduction}

Lentil (Lens culinaris L.) occupies the top position in terms of popularity and has been placed second in respect of area and production in Bangladesh ${ }^{1}$. It is cultivated during rabi season under rainfed condition. About $80 \%$ of total lentil in the country is grown in Faridpur, Kustia, Jessore, Rajshahi and Pabna. The yield of lentil is very poor. There is a great possibility to increase its production by exploiting better colonization of their root and rhizosphere through Rhizobium bacteria, which can reduce nitrogenous fertilizer use and protect environment. But Bangladesh soils have lack of sufficient and effective Rhizobium strains in most of the cases ${ }^{2}$. Moreover, degradation of Rhizobium occurs regularly. So, collection and screening of new Rhizobium strains and their sub-culturing and testing are necessary for quality inoculant production. For this reason, indigenous Rhizobium strains were collected from different AEZs of Bangladesh for lentil and were screened. Their efficiency in lentil production needs to be tested. The present study was, therefore under taken to find out the effectiveness of some Rhizobium strain/(s) on lentil at Regional Agricultural Research Station (RARS), Jamalpur (Agroecological Zone, AEZ-9) of Bangladesh.

\section{Materials and Methods}

A field experiment was conducted at Regional Agricultural Research Station (RARS), Bangladesh Agricultural Research Institute (BARI), Jamalpur under Old Brahmaputra Floodplain Soils and in Agro-ecological Zone 09 during rabi season of 2005-2006 and 2006-2007 to find out the effectiveness of Rhizobium strains on lentil. The initial soil sample of the experimental field was collected and analyzed following standard procedures in the laboratory and are presented in Table 1.

The soil was neutral (pH 7.00) having low organic matter (0.47\%). The content of total- $\mathrm{N}$ and exchangeable $\mathrm{K}$ was very low. The available phosphorus, sulphur and boron content were medium while zinc was low. The initial rhizobial population of the soil was below $10^{3}$. The experiment was laid out in randomized complete block design considering four replications. The unit plot size was $4 \mathrm{~m} \times 3 \mathrm{~m}$. The variety BARI Masur-4 of lentil and peat based rhizobial inocula BARI RLc-104, BARI RLc-105, BARI RLc-106 and BARI RLc-107 were used for the experiment. There were six treatments, $\mathrm{T}_{1}$ : Rhizobium strain BARI RLc-104, $\mathrm{T}_{2}$ : Rhizobium strain BARI RLc-105, $\mathrm{T}_{3}$ : Rhizobium strain BARI RLc-106, $\mathrm{T}_{4}$ : Rhizobium strain BARI RLc-107, $\mathrm{T}_{5}$ : mixed culture of the above

* Corresponding author:

Dr. M Asadul HaqueBhuiyan, Senior Scientific Officer, Soil Microbiology Laboratory, Bangladesh Agricultural Research Institute, Gazipur-1701, Bangladesh, Tel. (Office): (02) 9261501-5 Extn.5476, Cell.01720051657,E mail: mahbhuiyan63@yahoo.bom 
Table 1. Fertility status of the initial soil of the experimental field

\begin{tabular}{lcccccccccccccc}
\hline Station & $\mathrm{pH}$ & $\mathrm{OM} \mathrm{( \% )}$ & $\begin{array}{c}\mathrm{Ca} \\
\mathrm{meq} / 100 \mathrm{~g}\end{array}$ & & $\begin{array}{c}\mathrm{K} \\
\mu \mathrm{gg}^{-1}\end{array}$ & $\begin{array}{c}\text { Total } \\
\mathrm{N} \mathrm{( \% )}\end{array}$ & $\mathrm{P}$ & $\mathrm{S}$ & $\mathrm{B}$ & $\mathrm{Cu}$ & $\mathrm{Fe}$ & $\mathrm{Mn}$ & $\mathrm{Zn}$ \\
\hline Jamalpur & 7.00 & 0.47 & 3.1 & 1.0 & 0.12 & 0.025 & 16 & 17 & 0.3 & 3.5 & 26 & 14.0 & 1.50 \\
Critical level & 2.0 & 0.8 & 0.2 & 0.12 & 14 & 14 & 0.2 & 1 & 10 & 5 & 2 & \\
\hline
\end{tabular}

four strains and $\mathrm{T}_{6}$ : control. The above peat based rhizobial inocula containing $10^{8}$ cells g $^{-1}$ inoculum were used @ $1.5 \mathrm{~kg} \mathrm{ha}^{-1}$. Chemical fertilizers i.e. $\mathrm{P}, \mathrm{K}, \mathrm{S}$ and $\mathrm{Zn}$ were applied in all treatments as basal dose at $22 \mathrm{~kg} \mathrm{P} \mathrm{ha}^{-1}$ from triple superphosphate, $42 \mathrm{~kg} \mathrm{~K} \mathrm{ha}^{-1}$ from muriate of potash, $20 \mathrm{~kg} \mathrm{~S} \mathrm{ha}^{-1}$ from gypsum and $5 \mathrm{~kg} \mathrm{Zn} \mathrm{ha}^{-1}$ from zinc oxide.

Lentil was sown on 21 November 2005 and 16 November 2006 with a spacing of $30 \mathrm{~cm} \times 10 \mathrm{~cm}$. During the course of the experiment, growth and development of plants in the field were carefully observed. Ten randomly selected plants along with roots were collected at 50\% flowering stage from each unit plot and dry weight of roots, shoots and nodules including nodule numbers were recorded. The plants were harvested on 02 March 2006 and 09 March 2007. Data on plant height, 1000-seed weight, stover yield and seed yield were also taken plot wise and expressed on hectare basis. All data were analyzed statistically.

\section{Results and Discussion}

Effects of rhizobial inoculants on nodule number plant ${ }^{-1}$, nodule weight (mg plant ${ }^{-1}$ ), root weight $\left(\mathrm{g} \mathrm{plant}^{-1}\right)$, shoot weight (g plant ${ }^{1}$ ), plant height (cm), 1000-seed weight (g), stover yield $\left(\mathrm{t} \mathrm{ha}^{-1}\right)$, seed yield $\left(\mathrm{t} \mathrm{ha}^{-1}\right)$ and percent yield increase over control are presented in Table 2. Inoculated plants produced significantly higher nodule number, nodule weight, root weight, shoot weight, stover yield and seed yield compared to non-inoculated treatments. Plant heights and 1000-seed weight in all treatments were insignificant. Plant height and 1000 -seed weight did not find any definite trend due to application of rhizobial inoculants.

Plants inoculated with Rhizobium strain BARI RLc-104 produced the highest number of nodules (12.84 plant $^{-1}$ in 2006 and 12.30 plant $^{-1}$ in 2007) (Table 2). All the Rhizobium strains including mixed culture recorded identical nodule number but significantly higher over non-inoculated control. It indicated that all the strains individually or in combination had the ability to produce higher number of nodules. The lowest nodule formation $\left(7.54\right.$ plant $^{-1}$ in 2006 and 6.05 plant $^{-1}$ in 2007) was noted in the treatment where no Rhizobium strain was used. These results were supported by many other workers that the Rhizobium was responsible for higher nodulation ${ }^{3-5}$. Significant differences among strains in number of nodules plant ${ }^{-1}$ were also found for lentils ${ }^{6}$. Awan ${ }^{7}$, Rahman et $a l^{8}$ also reported that seed inoculation improved nodulation compared with the non-inoculated control.

Table 2. Effect of Rhizobium strains on nodulation, dry matter production and yield of lentil

\begin{tabular}{|c|c|c|c|c|c|c|c|c|c|}
\hline Treatment & $\begin{array}{c}\text { Nodule } \\
\text { number } \\
\text { plant }^{-1}\end{array}$ & $\begin{array}{c}\text { Nodule } \\
\text { weight (mg } \\
\text { plant }^{-1} \text { ) }\end{array}$ & $\begin{array}{c}\text { Root } \\
\text { weight (g } \\
\text { plant }^{-1} \text { ) }\end{array}$ & $\begin{array}{c}\text { Shoot } \\
\text { weight (g } \\
\text { plant }^{-1} \text { ) }\end{array}$ & $\begin{array}{l}\text { Plant } \\
\text { height } \\
(\mathrm{cm})\end{array}$ & $\begin{array}{c}\text { Stover } \\
\text { yield } \\
\left(\mathrm{t} \mathrm{ha}^{-1}\right)\end{array}$ & $\begin{array}{l}\text { 1000-seed } \\
\text { weight (g) }\end{array}$ & $\begin{array}{c}\text { Seed } \\
\text { yield } \\
\left(\mathrm{t} \mathrm{ha}^{-1}\right)\end{array}$ & $\begin{array}{c}\text { Yield } \\
\text { increase over } \\
\text { control (\%) }\end{array}$ \\
\hline BARI RLc-104 & $12.84 \mathrm{a}$ & $10.51 \mathrm{a}$ & $0.10 \mathrm{a}$ & $1.12 \mathrm{a}$ & 31.5 & $1.45 a$ & 18.7 & 1.23a & 55.7 \\
\hline BARI RLc-105 & $11.54 a$ & $9.01 \mathrm{~b}$ & 0.09ab & $0.88 \mathrm{bc}$ & 30.4 & $1.24 \mathrm{~b}$ & 18.0 & 1.03a & 24.0 \\
\hline Mixed culture & $11.97 \mathrm{a}$ & $9.02 b$ & $0.09 \mathrm{ab}$ & $1.08 \mathrm{a}$ & 29.5 & $1.30 \mathrm{ab}$ & 17.1 & $1.08 \mathrm{a}$ & 36.7 \\
\hline Control & $7.54 b$ & $6.21 \mathrm{c}$ & $0.08 b$ & $0.80 \mathrm{c}$ & 29.0 & $1.03 \mathrm{c}$ & 18.1 & $0.79 b$ & - \\
\hline CV (\%) & 8.6 & 10.2 & 10.0 & 12.6 & 5.0 & 10.0 & 6.8 & 13.2 & - \\
\hline \multicolumn{10}{|l|}{2007} \\
\hline BARI RLc-107 & $12.18 \mathrm{a}$ & $13.01 \mathrm{a}$ & 0.09a & $0.91 \mathrm{ab}$ & 35.5 & $1.45 a b$ & 20.4 & $1.20 \mathrm{a}$ & 50.0 \\
\hline Mixed culture & $11.08 \mathrm{a}$ & $11.21 \mathrm{a}$ & $0.08 \mathrm{a}$ & $0.99 a$ & 33.7 & $1.46 \mathrm{ab}$ & 19.8 & $0.91 \mathrm{ab}$ & 13.8 \\
\hline Control & $6.05 b$ & $7.00 \mathrm{~b}$ & $0.07 b$ & $0.71 b$ & 32.3 & $1.13 c$ & 20.6 & $0.80 \mathrm{~b}$ & - \\
\hline CV (\%) & 14.6 & 20.7 & 7.5 & 19.1 & 8.4 & 9.1 & 6.8 & 13.2 & - \\
\hline
\end{tabular}

Means followed by common letter are not significantly different at 5\% level by DMRT 
The highest nodule weight (10.51 mg plant $^{-1}$ in 2006 and 13.53 mg plant $^{-1}$ in 2007) was observed in BARI RLc-104 strain which was significantly higher over BARI RLc-105, mixed culture and noninoculated control in 2006, and identical to all other strains including mixed culture but different from non-inoculated control in 2007 (Table 2). All the strains recorded significantly higher nodule weight over non-inoculated control. BARI RLc-105 failed to produce higher nodule weight over non-inoculated control in 2007 and non-inoculated plants showed poor performance like nodule number. These results shows similarity with previous findings ${ }^{4-5,9}$. Significant differences among strains in nodule weight plant ${ }^{-1}$ were also found for lentils ${ }^{6,8}$.

Plants inoculated with BARI RLc-104 strain also gave the highest root weight (0.10 g plant $^{-1}$ in 2006 and 0.09 g plant $^{-1}$ in 2007) (Table 2). Strain BARI RLc-105, BARI RLc-106, BARI RLc-107 and mixed culture did not show significant effect on root weight over non-inoculated control in 2006 but all the strains showed significantly higher root weight in 2007. All the strains recorded identical root weight. This was supported by the findings of other groups $^{5,10}$.

Strain BARI RLc-104, BARI RLc-107 and mixed culture recorded significant effect on shoot weight over non-inoculated control in 2006 and only mixed culture had significant effect in 2007. Bhuiyan et $a .^{9}$ observed that strains resulted higher shoot weight in groundnut. Rahman et al. ${ }^{8}$ also noted that rhizobial strains gave higher shoot weight in lentil.

Strains had also significant effect on stover yields in both the years. Among the four strains and mixed culture, BARI RLc-104 gave the highest stover yield (1.45 tha-1 in 2006 and $1.58 \mathrm{t} \mathrm{ha}^{-1}$ in 2007). This result was supported by Kumar and Agarwal ${ }^{10}$ and Bhuiyan et al. ${ }^{4,12}$.

Plant height and 1000-seed weight in all the strains were found non-significant and this two parameters did not find any definite trend like others. These results were supported by Bhuiyan et al. ${ }^{13}$ that Rhizobium strain did not show significant effect on plant height and 1000-seed weight in soybean. Strains had no effect on plant height in lentil which was also observed by Rahman et $a .^{8}$.

Significant positive effect of Rhizobium inoculation on seed yield of lentil over non-inoculated control both in 2006 and 2007 was observed (Table 2). Strain BARI RLc-104 recorded the highest seed yield of 1.23 t ha $^{-1}$ (55.7\% higher over non-inoculated control) in 2006 and BARI RLc-107 recorded the highest seed yield of 1.20 t ha $^{-1}$ (50.0\% higher over non-inoculated control) in 2007. All the strains gave identical yield in both the years but different from non-inoculated control in 2006. In 2007, only BARI RLc-104 and BARI RLc-107 gave significantly higher seed yield over noninoculated control. Higher nodulation, dry matter production and seed yields might be due to the effect of Rhizobium inoculation on lentil. Bremer et al. ${ }^{6}$ reported that inoculation increased lentil yields by up to $135 \%$. Namdeo et al. ${ }^{14}$ also observed that inoculation increased lentil seed yield by $17.5-23.2 \%$ compared with no inoculation. In the present study, Rhizobium strains increased 14 to 56\% higher yield. The results were in agreement with the findings of other researchers who worked on lentil where Rhizobium inoculation gave higher yield ${ }^{11,15-17}$. These results were also supported by others $9,12,18-20$.

Table 3. Correlation matrix among different parameters of lentil

\begin{tabular}{|c|c|c|c|c|c|c|c|}
\hline \multirow[t]{2}{*}{ Characters } & \multirow[t]{2}{*}{ Year } & \multicolumn{6}{|c|}{ Correlation coefficient (r value) } \\
\hline & & Nodulenumber & Nodule weight & Root weight & Shoot weight & Plant height & Stover yield \\
\hline \multirow[t]{2}{*}{ Nodule weight } & 2006 & $0.880^{* *}$ & & & & & \\
\hline & 2007 & $0.768^{* *}$ & & & & & \\
\hline \multirow[t]{2}{*}{ Root weight } & 2006 & $0.623^{* *}$ & $0.720^{* *}$ & & & & \\
\hline & 2007 & $0.691^{* *}$ & $0.603^{* *}$ & & & & \\
\hline \multirow[t]{2}{*}{ Shoot weight } & 2006 & $0.684^{* *}$ & $0.752^{* *}$ & $0.739^{* *}$ & & & \\
\hline & 2007 & $0.661^{* *}$ & $0.292^{\mathrm{NS}}$ & $0.268^{\mathrm{NS}}$ & & & \\
\hline \multirow[t]{2}{*}{ Plant height } & 2006 & $0.567^{* *}$ & $0.622^{* *}$ & $0.476^{*}$ & $0.416^{*}$ & & \\
\hline & 2007 & $0.261^{\mathrm{NS}}$ & $0.524^{* *}$ & $0.308^{\mathrm{NS}}$ & $-0.150^{\mathrm{NS}}$ & & \\
\hline \multirow[t]{2}{*}{ Stover yield } & 2006 & $0.585^{* *}$ & $0.620^{* *}$ & $0.366^{\mathrm{NS}}$ & $0.366^{\mathrm{NS}}$ & $0.230^{\mathrm{NS}}$ & \\
\hline & 2007 & $0.902^{* *}$ & $0.787^{* *}$ & $0.636^{* *}$ & $0.646^{* *}$ & $0.360^{\mathrm{NS}}$ & \\
\hline \multirow[t]{2}{*}{ Seed yield } & 2006 & $0.534^{* *}$ & $0.486^{*}$ & $0.425^{*}$ & $0.483^{*}$ & $0.049^{\mathrm{NS}}$ & $0.322^{\mathrm{NS}}$ \\
\hline & 2007 & $0.719^{* *}$ & $0.576^{* *}$ & $0.435^{*}$ & $0.516^{* *}$ & $0.265^{\mathrm{NS}}$ & $0.675^{* *}$ \\
\hline
\end{tabular}

r values with 22 d.f., $1 \%$ level $=404,5 \%$ level $=515$

*Significant at $5 \%$ level, ${ }^{* *}$ Significant at $1 \%$ level, NS: Non-significant 


\section{Correlation}

Correlation matrix among the plant characters of lentil has been shown in Table 3. Some plant characters were strongly correlated among themselves. A significant and positive correlation was observed between nodule number and nodule weight, root weight, shoot weight, stover yield and seed yield; nodule weight and root weight, stover yield, seed yield; root weight and seed yield; shoot weight and seed yield in both the years. These results confirmed the findings of Bhuiyan et al. ${ }^{13,20}$. They observed positive and significant correlation of nodule number with nodule weight, root weight, and shoot weight of inoculated chickpea and soybean. Solaiman ${ }^{21}$ and Bhuiyan ${ }^{22}$ found positive correlation among mungbean growth and yield parameters.

\section{References}

1. Bangladesh Bureau of Statistics. 2006. Statistical Yearbook of Bangladesh. 26th Edition. Bangladesh Bureau of Statistics. Planning Division, Ministry of Planning, Govt. People’s Republic of Bangladesh, Dhaka, Bangladesh. pp. 143.

2. Khanam DK, Bhuiyan MAH, Rahman MHH and Hossain AKM. 1999. On-farm experience of the application and adoption of biological nitrogen fixation technology in Bangladesh. Bangladesh J. Agril. Res. 24(2): 375-382.

3. Podder AK. 1994. Performance of single and mixed rhizobial inocula for nodulation and growth of lentil. LENS Newsletter 21(1): 39-40.

4. Bhuiyan MAH, Rahman MM, Khanam D and Khaleque MA. 1998a. Nodulation and yield of groundnut in relation to strains of Bradyrhizobium. Bangladesh J. Sci. Ind. Res. 33(3): 323-326.

5. Eusuf Zai AK, Khanam D, Ullah MH, Bhuiyan MAH and Quamruzzaman AKM. 2004. Effect of Rhizobium inoculation on gardenpea (Pisum sativum) in Noncalcareous Grey Flood plain Soil of Bangladesh. Thai J. Agric. Sci. 37(4): 299-304.

6. Bremer E, Kessel C, Nelson L, Rennie RJ, Rennie DA and Van-Kessel C. 1990. Selection of Rhizobium leguminosarum strains for lentil (Lens culinaris) under growth room and field conditions. Plant Soil. 121(1): 47-56.

7. Awan MFM. 1994. Ontogenetic variation of nodulation, nitrogen fixation and nitrogen accumulation in lentil (Lens culinaris Medic) I. Soil characteristics, nodulation and plant yield. Acta Physiologiae Plantarum. 16(3): 163-169.

8. Rahman AKMH., Bhuiyan MAH, Khanam D, Ali ME and Alam F. 2009. Effect of Rhizobium strains on nodulation, dry matter production and yield of lentil. Bangladesh J. Agriculturists. 2(2): 133-136.
9. Bhuiyan MAH, Rahman MM, Khanam D and Basak NC. 2000. Effects of different Bradyrhizobium strains on nodulation, dry matter production and yield of groundnut. Bangladesh J. Microbiol. 17(1): 41-44.

10. Dravid MS. 1991. Effect of salinization, Rhizobium inoculation, genotypic variation and P-application on dry matter yield and utilization of P by pea (Pisum satimun L.) and lentil (Lens culinaris Medic). J. Nuclear Agric. Biol. 19(4): 227-231.

11. Kumar P and Agarwal JP. 1993. Response of lentil to Rhizobium inoculation, nitrogen and phosphorus fertilization. Indian J. Agron. 38(2): 318-320.

12. Bhuiyan MAH, Khanam D, Rahman MM and Ali MM. 1998b. Variation in the symbiotic effectiveness of Bradyrhizobium strains on soybean. Bangladesh J. Microbiol. 15(1): 25-30.

13. Bhuiyan MAH, Khanam D, Rahman MM and Talukder MZI. 2001a. Response of soybean to inoculation with different strains of Bradyrhizobium. Bangladesh J. Agril. Res. 26(4): 529-534.

14. Namdeo SL. Gupta SC. and Joshi RK. 1996. Influence of rhizobial inoculation on nodulation and yield of lentil genotypes under rain fed conditions. LENS Newsletter. 23(1\& 2): 24-26.

15. Bhuiyan MAH, Kabir MS and Khanam D. 1998c. Effects of boron, molybdenum and rhizobial inoculation on nodulation and yield of lentil. Bangladesh J. Seed Sci. Tech. 21(1\&2): 39-44.

16. Khanam D, Rahman MHH, Bhuiyan MAH, Islam MZ, Rahman AFM and Hossain AKM. 1996. Varietal screening of lentil (Lens culinaris L.) in presence and absence of Rhizobium inoculation. Progress. Agric. 7(2): 143-146.

17. Khanam D, Bhuiyan MAH, Rahman MHH and Hossain AKM. 1999. On-farm experience of the application and adoption of biological nitrogen fixation technology in Bangladesh. Bangladesh J. Agril. Res. 24(2): 375-382.

18 Yanni YG. 1992. Performance of chickpea, lentil and lupin nodulated with indigenous or inoculated rhizobia micropartners under nitrogen, boron, cobalt and molybdenum fertilization schedules. World $J$. Microbiol. Biotech. 8(6): 607-613.

19 Kantar F, Kiziloglu T, Caglar O and Akien S. 1995. Lentil yield in relation to Rhizobium leguminosarum inoculation in eastern Anatolia. LENS Newsletter. 21(2): 36-40.

20 Bhuiyan MAH, Khanam D, Khatun A, Hossain AKM and Islam MS. 2001b. Nodulation, dry matter weight and grain yield of chickpea as influenced by Rhizobium inoculation. Bangladesh. J. Agril. Res. 26(3): 463-466.

21 Solaiman ARM. 1999. Response of mungbean to Bradyrhizobium sp. (Vigna) inoculation with and without phosphorus and potassium fertilization. Bangladesh J. Sci. Res. 17(2): 125-132.

22 Bhuiyan MAH 2004. Evaluation of introducing mungbean into cereal based cropping pattern for sustainable soil fertility and productivity. Ph.D Thesis, Dept. of Soil Science, Bangladesh Agricultural University, Mymensingh. 